\title{
Nitrogen Fertilization on a Soybean Crop Grown on Black Oat and Forage Pea Straw in a Clayey Latosol in Western Paraná
}

\author{
Lucas da Silveira ${ }^{1}$, Deonir Secco ${ }^{1}$, Luiz Antônio Zanão Júnior ${ }^{2}$, Luciene Kazue Tokura ${ }^{1}$, \\ Reginaldo Ferreira Santos ${ }^{1}$, Bruna de Villa ${ }^{1}$, Pablo Chang ${ }^{1}$, Claudia Borgmann ${ }^{1}$, Simone Andreia Roehrs ${ }^{1}$, \\ Fernando Muller ${ }^{1} \&$ Caroline Beal Montiel ${ }^{1}$ \\ ${ }^{1}$ Graduate Program, Master's in Engineering of Energy in Agriculture, State University of West Paraná, \\ Cascavel, Paraná, Brazil \\ ${ }^{2}$ Agronomic Institute of Paraná, Santa Tereza do Oeste, Paraná, Brazil \\ Correspondence: Lucas da Silveira, Graduate Program, Master's in Engineering of Energy in Agriculture, State \\ University of West Paraná (UNIOESTE), Rua Universitária, 2069-Jardim Universitário, CEP: 85819-110, \\ Cascavel, Paraná, Brazil. Tel: 55-453-220-3151. E-mail: lucassbertolino@gmail.com
}

Received: February 11, 2019

Accepted: March 18, 2019 Online Published: May 31, 2019

doi:10.5539/jas.v11n7p196

URL: https://doi.org/10.5539/jas.v11n7p196

\begin{abstract}
The beneficial effects to the soil, when using cover crops, are numerous, such as nutrient cycling, nitrogen fixation, breaking of the cycle of pests and diseases, soil structuring and addition of dry matter. This makes the subsequent crop better able to express its productive potential. The nitrogen is a key element for any plant, especially in the early stages of crop development. In this way, the purpose of this study work was to evaluate the effect of nitrogen doses on the grain yield of soybeans grown on black oat and forage pea straw in a clayey Latosol in the western region of Paraná, Brazil. The experiment was conducted in the experimental area of the Agronomic Institute of Paraná (IAPAR), in the regional hub of Santa Tereza do Oeste. The local soil is classified as a typical Dystrophic Red Latosol. The experimental design consisted of a randomized complete block design with five replicates. The treatments consisted of nitrogen doses of $0,25,50,75$ and $100 \mathrm{~kg} \mathrm{ha}^{-1}$ applied in a broadcasting cover, without incorporation, using urea as a nitrogen source, at 20 days after emergence when the plants were in stage V3. The soil physical attributes were bulk density, total porosity, microporosity, and macroporosity. In the soybean crop, the production components evaluated were: plant height, 100-grain weight, and grain yield of grains. The data were submitted to analysis of variance, in which, for the quantitative factors, a regression analysis was performed and, for the qualitative characteristics, the Tukey test $(p<0.05)$ was performed. The mineral addition of nitrogen did not lead to an increase in grain yield of the cultivated soybean on the species of oat or forage pea cover. Thus, it can be stated that in well-structured clayey Latosols with high fertility, the nitrogen present in the soil organic matter and what was fixed symbiotically is sufficient to supply the nitrogen demand for the soybean crop.
\end{abstract}

Keywords: nitrogen, soybean production components, physical attributes, and soil fertility

\section{Introduction}

With the use of soil cover plants, diversity and the stability of the no-till system (NTS) occurs. Resources such as water and nutrients are used in a rational way, thereby providing gains for the system itself in terms of fertility and soil physics (Moro et al., 2013; Araujo et al., 2015; Farias et al., 2015).

Plenty of nutrients are found in crop residue. Their availability for crops installed later may be fast and intense or slow and gradual, and factors such as temperature, rainfall, and soil macro- and microbiology exert a strong influence on the availability of these nutrients (Crusciol et al., 2008; Teixeira, 2010; Teixeira et al., 2012).

Organic matter is the source of nutrients for plants, as nitrogen $(\mathrm{N})$ is present in organic matter. Most of the $\mathrm{N}$ is found in the organic fraction of the soil and, in smaller amounts, in inorganic form. In the inorganic fraction, $\mathrm{N}$ is found in nitric $\left(\mathrm{NO}_{3}{ }^{-}\right)$and ammoniacal $\left(\mathrm{NH}_{4}{ }^{+}\right)$forms. It is in these forms that $\mathrm{N}$ is absorbed and assimilated by the plant (Taiz \& Zeiger, 2010). 
Certain legume species have the ability to add large amounts of $\mathrm{N}$ to production systems. They are associated with the bacteria that fix the atmospheric $\mathrm{N}_{2}$, thereby resulting in productivity gains of successive or intercropped crops (Salmi et al., 2013).

Soybean (Glycine max L. Merril) is the most economically significant crop in Brazil. Its great expansion in all parts of the country is due to its ability to fix atmospheric nitrogen in association with the bacterium Bradyrhizobium japonicum (Fagan et al., 2007; Marcon et al., 2017).

Nitrogen is the most required element by the soybean crop. Their grains are high in protein, with an average content of $6.5 \% \mathrm{~N}$. It is estimated that, in order to produce $1000 \mathrm{~kg}$ of soybeans, $83 \mathrm{~kg}$ of N are required $(51 \mathrm{~kg}$ of $\mathrm{N}$ for the grains, with the remaining $32 \mathrm{~kg}$ intended for other parts of the plant) (EMBRAPA, 2011).

Studies developed involving the supplemental use of $\mathrm{N}$ in soybean present contradictions, which are related to the complexity involving the relation between rhizobium and the plant (Marcon et al., 2017). A number of factors, such as management, climate and relief, influence this interaction and can, therefore, provide results that question the adoption of this supplementation practice in the crop (Bahry et al., 2013; Marcon et al., 2017).

Denison and Harter (1995) report that the application of nitrogen fertilizers in legumes may cause a negative effect on natural biological fixation, affecting the availability of oxygen in the bacteria. Stephens and Neyra (1983), in turn, state that mineral nitrogen application limits the entry of carbohydrates into the metabolism of nodules.

Barry et al. (2013), when working with urea $(46 \% \mathrm{~N})$ tested different doses of $\mathrm{N}\left(0,30,60,90,120 \mathrm{~kg} \mathrm{ha}^{-1}\right)$ on different reproductive stages of soybeans, did not obtain significant results in soybean grain yield, even with the application of different doses in different phases.

According to Araújo and Carvalho (2006), in certain situations, the use of $20-30 \mathrm{~kg} \mathrm{ha}^{-1} \mathrm{~N}$ is proposed at sowing, in order to ensure the presence of $\mathrm{N}$ until the beginning of nodulation. In turn, Hungria et al. (2000) claimed that the insertion of $20 \mathrm{~kg} \mathrm{ha}^{-1} \mathrm{~N}$ at sowing resulted in a $14 \%$ decrease in nodulation and a $147 \mathrm{~kg} \mathrm{ha}^{-1}$ reduction in grains.

Mendes, Hungria, and Vargas (2000) also report that, in first-crop areas, in which the quantity of N-fixing bacteria is low, an initial negative nodulation disturbance occurs in soybeans, due to the use of small doses or "starting" doses at sowing.

With the knowledge of the beneficial effects of the use of cover crops and that the applications of nitrogen fertilizers of mineral origin may or may not complement natural biological fixation and, subsequently, increase soybean grain yields, this study aims to evaluate the effect of doses of $\mathrm{N}$ in the grain yield of soybeans grown on black oats and forage pea straw in a clayey Latosol in the western region of Paraná, Brazil.

\section{Material and Methods}

\subsection{Experimental Area}

The study was conducted in the 2016/2017 crop, under a no-till system, with soybean cultivation after black oat and forage pea cultivation. In 2016, prior to the implantation of the winter crops, soil samples were collected for soil chemical characterization in the $0-0.10 \mathrm{~m}$ layer. The chemical analysis had the following characteristics: $\mathrm{P}=$ $11.7 \mathrm{mg} \mathrm{dm}{ }^{-3} ; \mathrm{C}=33.5 \mathrm{~g} \mathrm{dm}^{-3} ; \mathrm{pH} \mathrm{CaCl}_{2}=4.8 ; \mathrm{Ca}=4.9 ; \mathrm{Mg}=2.1 ;$ and $\mathrm{K}=0.55 \mathrm{cmol}_{\mathrm{c}} \mathrm{dm}^{-3}$, and $\mathrm{V}=50 \%$.

The experimental area is located at the Paraná Agronomic Institute Station, in the municipality of Santa Tereza do Oeste, PR, Brazil, at coordinates $25^{\circ} 04^{\prime} 57.22^{\prime \prime}$ South (latitude) and $53^{\circ} 35^{\prime} 03.33^{\prime \prime}$ West (longitude), with a mean altitude of $757 \mathrm{~m}$. The soil is classified as typical Dystroferric Red Latosol, with a clayey to very clayey texture, smooth-wavy relief, and basalt substrate (EMBRAPA, 2013).

\subsection{Characterization of the Treatments}

The experimental design consisted of a randomized complete block design with five replicates. The treatments consisted of the nitrogen doses of $0,25,50,75$ and $100 \mathrm{~kg} \mathrm{ha}^{-1}$.

The experimental units were composed of 9 lines, with $5.1 \mathrm{~m}$ in length, spaced at $45 \mathrm{~cm}$, totaling $20.6 \mathrm{~m}^{2}$. The collected area was formed by five central lines, discarding $2.5 \mathrm{~m}$ from the ends, totaling $11.475 \mathrm{~m}^{2}$.

The desiccation of the area was performed when the black oats were in the grain-filling stage, and the forage pea were in the stage of producing flowers and pods. In the chemical management of the species, the systemic herbicide with the active principle glyphosate was used in the proportion of $4.0 \mathrm{~L} \mathrm{ha}^{-1}+$ mineral oil from the distillation of the oil in the proportion of $0.3 \mathrm{~L} \mathrm{ha}^{-1}$. 
The soybean cultivar chosen was BMX Lança IPRO. The basic fertilization was carried out alongside sowing, with application of $300 \mathrm{~kg} \mathrm{ha}^{-1}$ of the fertilizer NPK 04-30-10.

The nitrogen fertilizer used was urea, which contains $46 \%$ nitrogen in its composition. Urea application was performed manually without incorporation, when the plants were in stage V3. The control of weeds, pests and diseases was carried out according to the technical recommendations of the crop.

The soybean harvest was carried out in March 2017 using an automated parcel harvester. The harvested soybeans were sent to the laboratory for cleaning, weighing, and determination of humidity. Subsequently, the productivity $\left(\mathrm{kg} \mathrm{ha}^{-1}\right.$ ) was calculated, correcting the $13 \%$ moisture, according to the Seed Analysis Rules (RAS) (Brasil, 1992).

After the harvest, the soil samples were collected for soil physical characterization, in which the bulk density, total porosity, microporosity and macroporosity of the soil were determined. In the collection, trenches were opened in each experimental plot and undisturbed samples were collected in volumetric stainless-steel rings with a volume of approximately $98 \mathrm{~cm}^{3}(5 \mathrm{~cm}$ in diameter and $5 \mathrm{~cm}$ in height) in three soil layers $(0-10,10-20$, and $20-30 \mathrm{~cm}$ ), with the aid of a soil hammer and a soil extractor. The procedures for calculating these physical attributes followed the methodology recommended by EMBRAPA (1997).

\subsection{Statistical Analysis}

The data were submitted to analysis of variance, in which, for the quantitative factors, the regression analysis was performed and, for the qualitative characteristics, the Tukey test $(p<0.05)$ was performed. Statistical analyses were performed using the Sisvar program, version 5.6 (Ferreira, 2011).

\section{Results and Discussions}

Table 1 shows the mean values of the soil physical attributes in the layers $0.0-0.1 ; 0.1-0.2$ and $0.2-0.3 \mathrm{~m}$ in the treatments involving the oat and forage pea species and four doses of nitrogen.

Table 1. Mean values of bulk density (Ds), total porosity (Pt), macroporosity (Macro) and microporosity (Micro) of the soil in the treatments involving cover species and four nitrogen doses, in layers of 0-0.1, 0.1-0.2 and $0.2-0.3 \mathrm{~m} \mathrm{n}$ depth (mean of five replicates)

\begin{tabular}{|c|c|c|c|c|c|c|c|c|}
\hline \multirow{2}{*}{ N Dose $\left(\mathrm{kg} \mathrm{ha}^{-1}\right)$} & \multicolumn{2}{|c|}{ Ds $\left(\mathrm{Mg} \mathrm{m}^{-3}\right)$} & \multicolumn{2}{|c|}{$\mathrm{Pt}(\%)$} & \multicolumn{2}{|c|}{ Macro (\%) } & \multicolumn{2}{|c|}{ Micro (\%) } \\
\hline & Oat & Pea & Oat & Pea & Oat & Pea & Oat & Pea \\
\hline \multicolumn{9}{|l|}{$0-0.1 \mathrm{~m}$ layer } \\
\hline 0 & 1.16 & 1.11 & 54.77 & 56.47 & 8.84 & 11.68 & 45.85 & 44.79 \\
\hline 25 & 1.17 & 1.13 & 54.47 & 55.92 & 8.68 & 9.11 & 47.92 & 46.80 \\
\hline 50 & 1.14 & 1.17 & 55.47 & 54.39 & 10.44 & 8.46 & 45.04 & 45.93 \\
\hline 75 & 1.15 & 1.15 & 55.04 & 55.25 & 8.96 & 7.89 & 46.09 & 47.36 \\
\hline 100 & 1.17 & 1.13 & 54.54 & 55.90 & 9.51 & 8.90 & 45.03 & 46.99 \\
\hline$\hat{\mathrm{y}}=\overline{\mathrm{y}}$ & 1.15 & 1.14 & 54.86 & 55.58 & 9.28 & 9.20 & 45.99 & 46.37 \\
\hline CV $(\%)$ & 3.11 & 3.64 & 2.68 & 2.95 & 14.99 & 13.83 & 5.96 & 3.69 \\
\hline \multicolumn{9}{|l|}{$0.1-0.2$ layer } \\
\hline 0 & 1.16 & 1.11 & 56.39 & 57.93 & 14.20 & 13.37 & 42.19 & 44.56 \\
\hline 25 & 1.13 & 1.15 & 57.27 & 56.37 & 14.70 & 13.02 & 42.57 & 43.34 \\
\hline 50 & 1.16 & 1.14 & 56.10 & 57.10 & 13.96 & 13.60 & 42.15 & 43.41 \\
\hline 75 & 1.17 & 1.13 & 55.75 & 57.55 & 14.17 & 13.31 & 41.57 & 44.24 \\
\hline 100 & 1.19 & 1.15 & 54.99 & 56.54 & 13.49 & 12.95 & 41.49 & 43.61 \\
\hline$\hat{\mathrm{y}}=\overline{\mathrm{y}}$ & 1.16 & 1.14 & 56.10 & 57.07 & 14.10 & 13.24 & 41.99 & 43.83 \\
\hline CV $(\%)$ & 3.51 & 4.32 & 2.69 & 3.21 & 9.30 & 11.39 & 3.22 & 3.40 \\
\hline \multicolumn{9}{|l|}{$0.2-0.3 \mathrm{~m}$ layer } \\
\hline 0 & 1.11 & 1.06 & 59.07 & 61.00 & 14.28 & 12.77 & 44.90 & 48.23 \\
\hline 25 & 1.12 & 1.05 & 58.93 & 61.25 & 14.87 & 12.87 & 44.07 & 48.68 \\
\hline 50 & 1.09 & 1.09 & 62.15 & 59.66 & 15.20 & 12.75 & 46.63 & 46.91 \\
\hline 75 & 1.15 & 1.07 & 56.04 & 60.31 & 18.23 & 12.50 & 37.81 & 47.80 \\
\hline 100 & 1.10 & 1.16 & 59.30 & 57.22 & 13.31 & 12.55 & 45.97 & 44.68 \\
\hline$\hat{\mathrm{y}}=\overline{\bar{y}}$ & 1.11 & 1.08 & 59.10 & 59.89 & 15.16 & 12.62 & 43.88 & 47.26 \\
\hline $\mathrm{CV}(\%)$ & 5.94 & 6.50 & 4.14 & 4.34 & 31.51 & 16.85 & 15.33 & 5.81 \\
\hline
\end{tabular}

Note. CV: Coefficient of variation. 
Bulk density (Ds) is the attribute that allows an inference of the conditions of soil compaction and the subsequent understanding of the occurrence or non-occurrence of physical impediments to the growth of the root system of the plants (Guariz et al., 2009). Ds varies according to the nature, size, shape and arrangement of the particles in the soil.

According to the results found in Table 1, the bulk density in the 0.0-0.1, 0.1-0.2 and 0.2-0.3 m layers did not present any significant difference between the treatments. The calculated values of the coefficient of variation for bulk density were $3.11 \%$ and $3.64 \%$ in the $0.0-0.1 \mathrm{~m}$ layer, $3.51 \%$ and $4.32 \%$ in the $0.1-0.2 \mathrm{~m}$ layer, and $5.94 \%$ and $6.50 \%$ in the $0.2-0.3 \mathrm{~m}$ layer.

It is observed that Ds presented an overall mean value of $1.13 \mathrm{Mg} \mathrm{m}^{-3}$ (Table 1) and that all treatments in both cover species and layers evaluated obtained results close to the general mean, which indicates an absence of physical impediment to the root growth of the soybean, as according to Reichert et al. (2009), for clayey soils, the critical level of Ds is $1.35 \mathrm{Mg} \mathrm{m}^{-3}$. In these conditions, they state that the soil may present restrictions to root growth for annual crops. According to Souza, Carneiro, \& Paulino (2005), however, the value of $1.40 \mathrm{Mg} \mathrm{m}^{-3}$ is the limit value for clayey soils.

Total porosity (Pt), according to Reinert and Reichert (2006), is responsible for a number of mechanisms of great magnitude in soil physics. Events such as water and air retention and flow are associated with the Pt rate. According to the results in Table 1, for soil Pt in the 0.0-0.1; 0.1-0.2 and 0.2-0.3 m layers did not present a significant difference between the treatments. It can be noted that the calculated coefficient of variation for Pt was $2.68 \%$ and $2.95 \%$ in the $0.0-0.1 \mathrm{~m}$ layer, $2.69 \%$ and $3.21 \%$ in the $0.1-0.2 \mathrm{~m}$ layer, and $4.14 \%$ and $4.34 \%$ in the $0.2-0.3$ m layer.

It is observed that Pt presented a mean value of $56.68 \%$ in the black oat crop and $57.51 \%$ in the forage pea crop (Table 1) and that all evaluated layers obtained results close to the overall mean for each crop.

This demonstrates that soil is in good structural condition due to the porous spaces contained in it. The mean values for the three evaluated layers are above $50 \%$, which is considered ideal for clayey Latosols, according to Lima, Pilon, and Lima (2007). This conclusion corroborates the results found by Andrade and Stone (2009), in which the authors report that a soil is required to have at least $50 \%$ total porosity to perform its functions in soil physics. According to Secco (2005), total porosity presents an inverse relationship with compaction and a direct relationship with penetration resistance.

Macropores consist of pores larger than or equal to $0.05 \mathrm{~mm}$, commonly referred to as non-capillary pores, as they do not have the function of storing water from the soil. Nevertheless, they are the main pores responsible for water and gas flows into the soil (EMBRAPA, 2003).

The mean values of macroporosity found in this study were $9.28 \%$ and $9.20 \%$ for the $0.0-0.1 \mathrm{~m}$ layer, $14.10 \%$ and $13.24 \%$ for the $0.1-0.2 \mathrm{~m}$ layer, and $15.16 \%$ and $12.62 \%$ for the $0.2-0.3 \mathrm{~m}$ layer. It is noted that in both crops, only the surface layer is below the critical value, which according to Prevedello (1996), Suzuki (2005) and Jong Van Lier (2010), is around $10 \%$ for the development of crops. Lower values cause a reduction in crop productivity.

Reichert, Suzuki, and Reinert (2007) also state that the critical values of macroporosity for plant growth are established, being close to $10 \%$. According to Gubiani (2012), however, these values are not yet fixed, as in soils managed under no-till systems and with excellent drainage, critical macroporosity values may be even lower.

The microporosity or capillary porosity is of great importance in the soil-water-plant relationship. These pores are responsible for storing and retaining water in the soil (Souza et al., 2010).

According to the results found in Table 1 , soil microporosity in the $0.0-0.1 \mathrm{~m}, 0.1-0.2 \mathrm{~m}$ and $0.2-0.3 \mathrm{~m}$ layers did not present significant differences. The mean values found in this study were $45.99 \%$ and $46.37 \%$ for the $0.0-0.1$ $\mathrm{m}$ layer, $41.99 \%$ and $43.83 \%$ for the $0.1-0.2 \mathrm{~m}$ layer, and $43.88 \%$ and $47.26 \%$ for the $0.2-0.3 \mathrm{~m}$ layer. According to Sanchez (2012), the ideal value for the layers sampled is around $40-43 \%$. It is observed that none of the layers is below the value considered critical by the researchers.

The mean values for plant height, 100-grain weight and grain yield evaluated in the soybean crop in the treatments involving the cover species and $\mathrm{N}$ doses are shown in Figures 1, 2 and 3 respectively.

Through the regression analysis, it was possible to note (Figure 1) that there was no significant difference between the plant height variable as a function of the nitrogen doses. It is observed that the soybean presented the same average plant height for both soil cover species. 

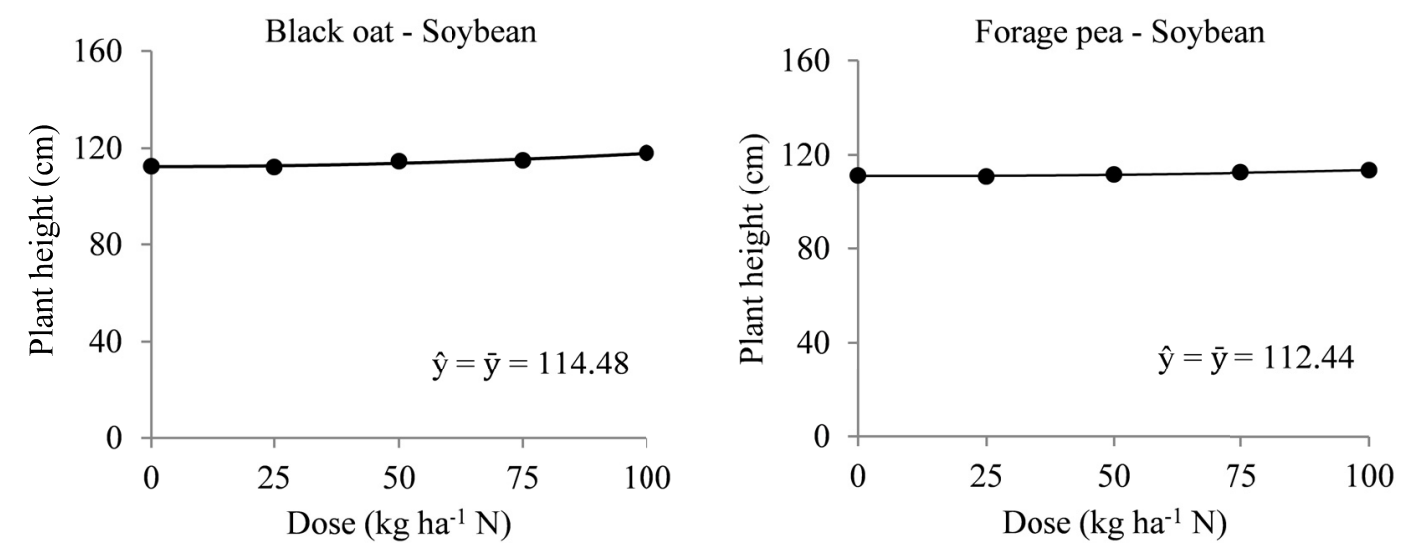

Figure 1. Plant height of the soybean plants as a function of the cover plants and nitrogen doses

This result does not corroborate the results found by Lopes (1998), who reports that, when there is nitrogen addition above the recommended dose, the crop presents a prolonged vegetative phase. One of the resulting characteristics is the increase in plant height. The maximum plant height reached by the soybean crop was 118 $\mathrm{cm}$ at the dose of $100 \mathrm{~kg} \mathrm{ha}^{-1} \mathrm{~N}$ after the cultivation of black oats and $113 \mathrm{~cm}$ at the dose of $100 \mathrm{~kg} \mathrm{ha}^{-1} \mathrm{~N}$ after the cultivation of the forage pea.

Variations in the weight of 100 grains can be influenced by the cultivar being used and by the manner the soil is being managed. The results of the variable of the weight of 100 grains (g) are shown in Figure 2, which shows that the soybean performance in this variable was identical for both cover species.
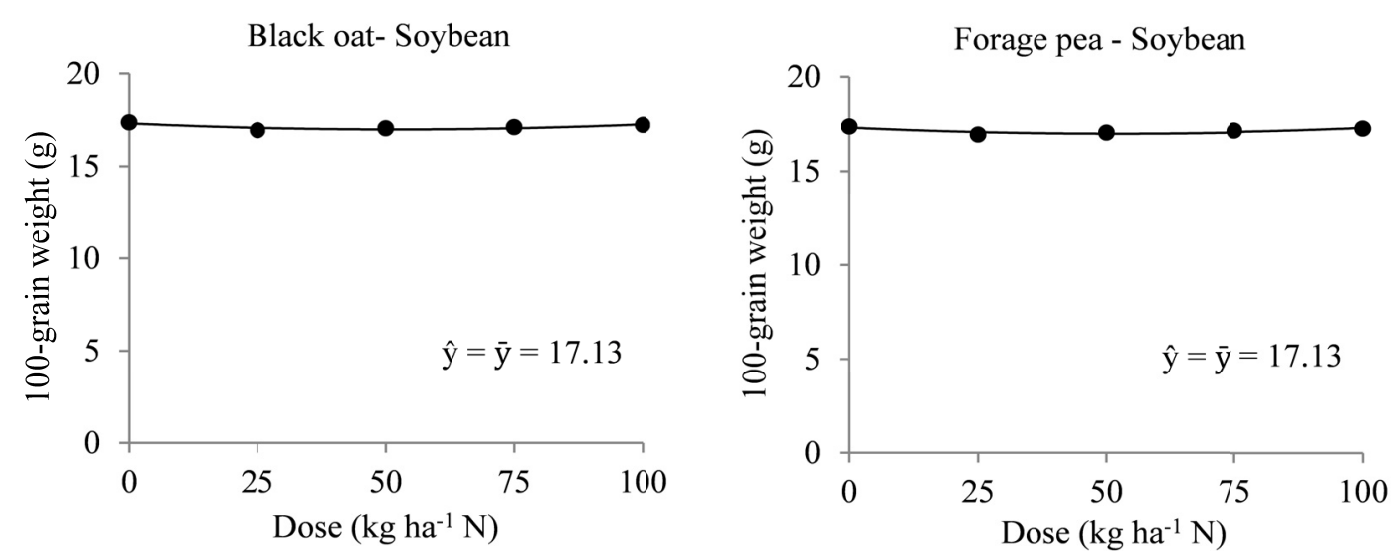

Figure 2. 100-grain weight (g) of soybean as a function of the cover crops and nitrogen doses

It is also observed that the control, without addition of nitrogen, had a performance similar to the other treatments, for both oats and forage pea, with the addition of $\mathrm{N}$ doses, and the variable relating to the weight of 100 grains did not suffer interference. Denison and Harter (1995) argue that when nitrogen is added through nitrogen fertilizers in legumes, the effect may be negative, rendering unfeasible the main form of addition of the element into the soil, through biological fixation.

The characteristic of the black oat crop is its high production potential of straw mass. Nevertheless, this same straw has a high $\mathrm{C} / \mathrm{N}$ ratio, which affects the decomposition rate of the phytomass. This slow decomposition causes nutrients contained in the oat biomass to be released slowly and gradually.

Figure 3 shows that the grain yield variable $\left(\mathrm{kg} \mathrm{ha}^{-1}\right)$ in the soybean crop showed no significant difference between the nitrogen doses. 

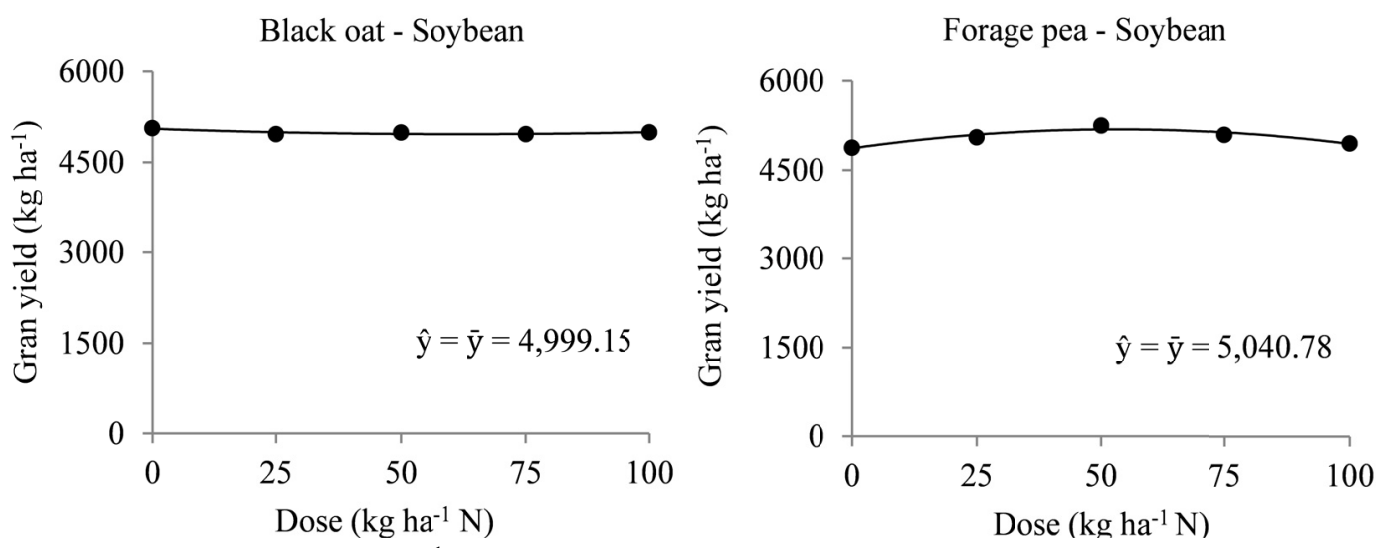

Figure 3. Grain yield $\left(\mathrm{kg} \mathrm{ha}^{-1}\right)$ of soybean, as a function of the cover crops and nitrogen doses

The grain yield of soybean grains after the cultivation of black oats did not differ among the evaluated treatments. This shows that the treatment without addition of $\mathrm{N}$ reached an average production of $5,067.83 \mathrm{~kg} \mathrm{ha}^{-1}$ and 68.68 $\mathrm{kg} \mathrm{ha}^{-1}$, a mean value statistically similar to that obtained from the other treatments. This shows that only the nitrogen contained in the organic matter of the soil or symbiotically fixed was able to supply the needs of the soybean crop.

These results corroborate the results found by Banry et al. (2000), who state that the application of mineral nitrogen in soybean, in any vegetative phase, does not result in grain yield gains. On the contrary, with the addition of these fertilizers, the reduction of natural biological fixation occurs (Amado, Mielniczuk, \& Fernandes, 2000).

The result found after forage pea cultivation is shown in Figure 3. The estimated mean productivity among all treatments was $5,048.78 \mathrm{~kg} \mathrm{ha}^{-1}$ of grains. It is observed that the addition of nitrogen doses did not result in productivity gains in the soybean crop cultivated on this species of cover.

The forage pea has a low $\mathrm{C} / \mathrm{N}$ ratio and undergoes a faster decomposition, as it does not have fibrous parts in its composition. This makes the release of the nutrients faster, and consequently, the soybeans can take advantage of these same elements since the beginning of their cycle.

\section{Conclusion}

The physical characteristics of the soil (bulk density, total porosity, macroporosity and microporosity) as well as the soy yields (plant height, 100 grain mass and grain yield) did not show significant differences between the treatments.

The mineral addition of nitrogen did not lead to an increase in grain yield in the soybean cultivated on the cover species of black oats or forage pea. With that, it can be said that, in well-structured clayey latosols with high fertility, the nitrogen present in the soil organic matter, as well as the nitrogen symbiotically fixed, is sufficient to supply the nitrogen demand for the soybean crop.

\section{References}

Amado, T. J. C., Mielniczuk, J., \& Fernandes, S. B. V. (2000). Legumes and mineral fertilizer as nitrogen sources to corn in tillage systems. Revista Brasileira de Ciência do Solo, 24, 179-189. https://doi.org/10.1590/S010006832000000100020

Andrade, R. S., \& Stone, L. F. (2009). S index as an indicator of physical quality of Brazilian 'Cerrado' soils. Revista Brasileira de Engenharia Agricola e Ambiental, 13(4), 382-388. https://doi.org/10.1590/S141543662009000400003

Araújo, A. S. F., \& Carvalho, E. M. S. (2006). Fixação biológica de nitrogênio em leguminosas (Comunicado Técnico 11, pp. 1-4). Teresina: UFPI. Retrieved from http://www.bdpa.cnptia.embrapa.br/consulta/busca?b= pc\&biblioteca $=$ vazio\&busca $=$ autoria:\%22ARA\%C3\%9AJO,\%20A.\%20S.\%20F.\%20de\%22

Araújo, L. S., Cunha, P. C. R., Silveira, P. M., Netto, M. S., \& Oliveira, F. C. (2015). Potential of soil coverage and suppression of purple nutsedge (Cyperus rotundus) by cover crop residues. Revista Ceres, 62(5), 483-488. https://doi.org/10.1590/0034-737X201865060001 
Bahry, C. A., Venske, E., Nardino, M., Fin, S. S., Zimmer, P. D., Souza, V. Q., \& Caron, B. O. (2013). Morphological traits and soybean yield components subjected to nitrogen fertilization. Revista Agrarian, 6(21), 281-288. https://doi.org/10.30612

Brasil. (1992). Ministério da Agricultura e da Reforma Agrária (p. 365). Regras Para Análise de Sementes. Brasília: SNDA/DNDV/CLAV.

Calegari, A., \& Pola, J. N. (2007). Ervilha forrageira Iapar 83. Retrieved from http://www.iapar.br/arquivos/ File/zip_pdf/ervilha-final.pdf

CONAB (Companhia Nacional de Abastecimento). (2012). Acompanhamento da Safra Brasileira 2012. Retrieved from http://www.cnpt.embrapa.br/biblio/do/p_do136_3.htm\#1

Crusciol, C. A. C., Moro, E., Lima, E., \& Andreoti, M. (2008). Decomposition rate and nutrient release of oat straw used as mulching in no-till system. Bragantia, 67(2), 481-489. https://doi.org/10.1590/S0006-8705200800 0200024

Denison, R. F., \& Harter, B. L. (1995). Nitrate effects on nodule oxygen permeability and leghemoglobin. Nodule oximetry and computer modeling. Plant Physiol., 107, 1355-1364. https://doi.org/10.1104/pp.107.4.1355

Derpsch, R., \& Calegari, A. (1992). Plantas para adubação verde de inverno (p. 80). Londrina: IAPAR.

EMBRAPA (Empresa Brasileira de Pesquisa Agropecuária). (1997). Manual de métodos de análise de solo: Centro Nacional de Pesquisa de Solos (2nd ed.). Rio de Janeiro: Embrapa. Retrieved from https://www. agencia.cnptia.embrapa.br/Repositorio/Manual+de+Metodos_000fzvhotqk02wx5ok0q43a0ram31wtr.pdf

EMBRAPA (Empresa Brasileira de Pesquisa Agropecuária). (2003). Manual de análises químicas de solos, plantas e fertilizantes: Tecnologias de Produção de Soja na Região Central do Brasil (2nd ed.). Brasília: Sistemas de Produção. Retrieved from http://livraria.sct.embrapa.br/liv_resumos/pdf/00053080.pdf

EMBRAPA (Empresa Brasileira de Pesquisa Agropecuária). (2011). Adubação verde. Utilização de leguminosas contribui no fornecimento de nitrogênio para culturas de interesse comercial e protege solo da erosão. Retrieved from https://www.embrapa.br/documents/1355054/1527012/4a+-+folder+Aduba $\% \mathrm{C} 3 \% \mathrm{~A} 7 \% \mathrm{C}$ 3\%A3o+verde.pdf/6a472dad-6782-491b-8393-61fc6510bf7d

EMBRAPA (Empresa Brasileira de Pesquisa Agropecuária). (2013). Sistema Brasileiro de Classificação dos Solos (3rd ed.). Rio de Janeiro: Embrapa. Retrieved from http://livraria.sct.embrapa.br/liv_resumos/pdf/ 00053080.pdf

Fagan, E. B., Medeiros, S. L. P., Manfron, P. A., Casaroli, D., Simon, J., Neto, D. D., ... Müller, L. (2007). Fisiology of biologic fixation nitrogen in soybean-A Review. Revista da Faculdade de Zootecnia, Veterinária e Agronomia, 14(1), 89-106.

Farias, D. B. dos S., Lucas, A. A. T., Moreira, M. A., Nascimento, L. F. de A., \& Filho, J. C. F. de. (2015). Soil moisture evaluation in function of organic matter presence and ground cover in lettuce growth (Lactuca sativa L.). Revista Brasileira de Agricultura Irrigada, 9(5), 287-291. https://doi.org/10.7127/rbai. v12n600828

Ferreira, D. F. (2011). Sisvar: A computer statistical analysis system. Ciência e Agrotecnologia, 35, $1039-1042$. https://doi.org/10.1590/S1413-70542011000600001

Guariz, H. R., Picoli, M. H. S., Campanharo, W. A., \& Cecílio, R. A. (2009). Variação da Umidade e da Densidade do Solo sob Diferentes Coberturas Vegetais. Revista Brasileira de Agroecologia, 4(2), 3293-3296.

Gubiani, P. I. (2012). Regularidade de resposta da cultura do milho à compactação do solo (Tese (Doutorado em ciência do solo), Universidade Federal de Santa Maria, Santa Maria). Retrieved from http://w3.ufsm.br/ ppges/images/Teses/PAULO-IVONIR-GUBIANI-TESE.pdf

Hungria, M., \& Vargas, M. A. T. (2000). Environmental factors affecting N2 fixation in grain legumes in the tropics, with an emphasis on Brazil. Field Crops Research, 65, 151-164. https://doi.org/10.1016/j.fcr. 2012.11 .018

Jong Van Lier, Q. de. (2010). Física do Solo (p. 298). Viçosa: Sociedade Brasileira de Ciência do Solo.

Lima, C. L. R., Pillon, C. N., \& Lima, A. C. R. (2007). Qualidade física do solo: indicadores quantitativos (p. 25, Documentos 196). Pelotas: Embrapa Clima Temperado. Retrieved from https://www.embrapa.br/climatemperado/busca-de-publicacoes/-/publicacao/745869/qualidade-fisica-do-solo-indicadores-quantitativos

Lopes, A. S. (1998). Manual internacional de fertilidade do solo (2nd ed., pp. 37-46). Piracicaba: Potafos. 
Marcon, E. C., Romio, S. C., Maccari, V. M., Klein, C., \& Lájus, C. R. (2017). Use of different sources of nitrogen in soybean crop. Revista Thema, 14(2), 298-308. https://doi.org/10.15536/thema.12.2015.2.344

Mendes, I. C., Hungria, M., \& Vargas, M. A. T. (2000). Resposta da soja à adubação nitrogenada na semeadura, em sistemas de plantio direto e convencional na região do cerrado (p. 15). Planaltina: Embrapa Cerrados. Retrieved from https://www.infoteca.cnptia.embrapa.br/bitstream/doc/557546/1/bolpd12.pdf

Moro, E., Crusciol, C. A. C., Nascente, A. S., \& Cantarella, H. (2013). Soil inorganic nitrogen content according to cover crops, nitrogen sources and nitrification inhibitor. Pesquisa Agropecuaria Tropical, 43(4), 424-435. https://doi.org/10.1590/1983-40632018v4852876

Prevedello, C. L. (1996). Física do solo com problemas resolvidos (p. 446). Curitiba: Saeafs.

Reichert, J, M., Suzuki, L. E. A. S., Reinert, D. J., Horn, R., \& Hakansson, I. (2009). Reference bulk density and critical degree-of-compactness for no-till crop production in subtropical highly weathered soils. Soil and Tillage Research, 102, 242-254. https://doi.org/10.1016/j.still.2017.07.015

Reichert, J. M., Suzuki, L. E. A. S., \& Reinert, D. J. (2007). Compactação do solo em sistemas agropecuários e florestais: Identificação, efeitos, limites críticos e mitigação. In C. A. Ceretta, L. S. Silva, \& J. M. Reichert (Eds.), Tópicos em ciência do solo (Vol. 5, pp. 49-134). Viçosa: Sociedade Brasileira de Ciência do Solo. https://doi.org/10.1590/18069657rbcs20151105

Reinert, D. J., \& Reichert, J. M. (2006). Propriedades físicas do solo (p. 18). Universidade Federal de Santa Maria. Retrieved from https:/www.agro.ufg.br/up/68/o/An_lise_da_zona_n_o_saturada_do_solo_texto.pdf

Salmi, A. P., Risso, I. A. M., Guerra, V. G. M., Urquiaga, S., Araujo, A. P., \& Abboud, A. C. S. (2013). Growth, nutrient accumulation and biological nitrogen fixation of Flemingia macrophylla. Revista Ceres, 60(1), 79-85 https://doi.org/10.1590/0034-737X201865060001

Sanchez, E. (2012). Propriedades físicas do solo e produtividade de soja em sucessão a plantas de cobertura de inverno (Dissertação (Mestrado em Agronomia), Universidade Estadual do Centro-Oeste, Guarapuava). Retrieved from http://unicentroagronomia.com/destino_arquivo/mestradoemmanuelsanchez.pdf

Sartori, V. C., Silva-Ribeiro, R. T., Scur, L., Pansera, M. R., Rupp, L. C. D., \& Venturin, L. (2011). Adubação verde e compostagem: Estratégias de manejo do solo para conservação das águas (p. 17). Caxias do Sul: Educs.

Secco, D., Ross, C. O. D., Secco, J. K., \& Fiorin, J. E. (2005). Crop yield and physical attributes of a clayey oxisol under different management systems. Revista Brasileira de Ciência do Solo, 29(3), 407-414. https://doi.org/ $10.1590 / 18069657 \mathrm{rbcs} 20151105$

Silveira, G., Moliterno, E., Ribeiro, G., Carvalho, F. I. F., Oliveira, A. C., Nornberg, R., Baretta, D., \& Mezzalira, I. (2010). Genetic variability for top agronomic characteristics in biparental crosses of black oats. Bragantia, 69(4), 823-832. https://doi.org/10.1590/S0006-87052010000400007

Souza, E. D., Carneiro, M. A. C., \& Paulino, H. B. (2005). Physical attributes of a Typic Quartzipisamment and a Rhodic Hapludox under different management systems. Pesquisa Agropecuária Brasileira, 40(11), 1135-1139. https://doi.org/10.1590/S0100-204X2005001100012

Souza, F. R., Junior, E. J. R., Fietz, C. R., Bergamin, A. C. B., Venturoso, L. R., \& Rosa, Y. B. C. J. (2010). Physical attributes and performance of soybean in Oxisol under two management systems. Ciência $e$ Agrotecnoloogia, 34(6), 1357-1364. https://doi.org/10.1590/S1413-70542010000600001

Stephens, B. D., \& Neyra, C. A. (1983). Redução de Nitratos e Nitritos em Relação à Atividade de Nitrogenase em Nódulos de Soja e Bacteróides de Rhizobium japonicum. Physiol Vegetal.

Suzuki, L. E. S. (2005). Compactação do solo e sua influência nas propriedades físicas do solo e crescimento e rendimento de culturas (Tese (Doutorado em ciência do solo), Universidade Federal de Santa Maria, Santa Maria). Retrieved from http://w3.ufsm.br/ppgcs/images/Dissertacoes/L.E.A.S.SUZUKI.pdf

Taiz, L., \& Zeiger. (2010). Plant Physiology (5th ed.). Sinauer Associates: Inc, USA.

Teixeira, M. B. (2010). Teores de nutrientes na palhada e no solo, após o corte das plantas de milheto e sorgo (Dissertação (Mestrado em Fitotecnia). Universidade Federal Rural do Rio de Janeiro, Seropédica, RJ). Retrieved from http://cursos.ufrrj.br/posgraduacao/ppgf/teses

Teixeira, M. B., Loss, A., Pereira, M. G., \& Pimentel, C. (2012). Nutrient cycling and decomposition of crop residues of four cover crops for soil. IDESIA, 30(1), 55-64. 


\section{Copyrights}

Copyright for this article is retained by the author(s), with first publication rights granted to the journal.

This is an open-access article distributed under the terms and conditions of the Creative Commons Attribution license (http://creativecommons.org/licenses/by/4.0/). 